Ann. Zootech., I975, 24 (I), 69-79.

\title{
TRANSIT DES ALIMENTS LIQUIDES AU NIVEAU DE LA GOUTTIERE ESOPHAGIENNE CHEZ LE VEAU PRÉRUMINANT ET RUMINANT
}

\author{
R. GUILHERMET, C.-M. MATHIEU et R. TOULLEC
}

avec la collaboration technique de Marguerite Beaufils, Monique Mansion et Y. Manis

Station de Recherches zootechniques,

Centre de Recherches de Rennes, I. N.R. A., École nationale supérieure agronomique,

65 , we de Saint-Brieuc,

35042 Rennes Cedex

\section{RÉSUMÉ}

Le fonctionnement de la gouttière osophagienne a été étudié èn mesurant la proportion de l'aliment liquide ingéré retrouvée dans le rumen après le repas. Pour cela, i 8 vcaux mâles ont été munis d'une fistule du rumen. Le polyéthylène glycol a été utilisé comme marqueur, il a été introduit d'une part directement par la fistule pour déterminer le volume du liquide ruminal et d'autre part dans l'aliment pour déterminer la concentration en polyéthylène glycol du liquide ruminal aussitôt après le repas. Les aliments ont été distribués au seau.

I. Cinq veaux préruminants de race Frisonne, alimentés au lait entier ont été maintenus au stade préruminant jusqu'à l'âge de 6 mois ; moins de ro p. roo du lait ingéré ont généralement été retrouvés dans le rumen. Cependant, chez un veau préruminant de race Pie Rouge, alimenté dans les mêmes conditions, de fortes proportions de lait ont parfois été retrouvées dans le rumen.

2. Sept veaux préruminants ont reçu occasionnellement en substitution au lait distribué habituellement des aliments liquides. Le lait écrémé, la suspension de tourteau de soja et la solution de concentré protéique de poisson ont été retrouvés en très faible proportion dans le rumen (o à I I p. Ioo en moyenne alors que le lactosérum l'a été en proportion plus importante (2 I à 45 p. roo en moyenne)).

3. Deux veaux ruminants ont continué à recevoir du lait entier jusqu'à l'âge d'un an. Moins de 20 p. Ioo du lait ont été retrouvés dans le rumen dans plus de 75 p. Ioo des essais. L'efficacité de la fermeture de la gouttière a semblé diminuer avec l'âge de l'animal.

4. Chez deux veaux ruminants, l'eau a été retrouvée en proportion plus importante dans le rumen chez l'animal qui en disposait à volonté que chez celui pour lequel elle était ôtée la nuit (63 et $29 \mathrm{p}$. Ioo en moyenne). L'efficacité de la fermeture de la gouttière a paru diminuer avec l'âge.

5. Deux veaux ruminants ont reçu une buvée exempte d'éléments lactés, en remplacement de l'aliment d'allaitement à partir de l'âge de 7 semaines. La buvée a été retrouvée en faible proportion dans le rumen (moins de $20 \mathrm{p}$. Ioo dans $96 \mathrm{p}$. Ioo des cas) jusqu'à l'àge de 4 mois, il en a été de même entre les âges de 7 et 8 mois après une interruption de 2 mois dans la distribution de la buvée.

Chez le Veau, les aliments liquides ingérés volontairement au seau passent donc directement dans la caillette en proportion très importante, quelle que soit leur nature chimique. La proportion retrouvée dans le rumen paraît cependant s'accroître avec l'âge chez le Veau ruminant, en particulier au-delà d'un an. 


\section{INTRODUCTION}

Le fonctionnement de la gouttière œsophagienne a été étudié par de nombreux auteurs et, selon HuNGATE (I966), c'est FABER (I65I) qui le premier a suggéré que le lait ingéré par les jeunes ruminants passait directement dans la caillette grâce au rapprochement des lèvres de la gouttière œesophagienne. FLourens (I844) a observé chez des ruminants adultes que les aliments liquides se retrouvaient dans les 4 réservoirs gastriques aussitôt après leur ingestion, alors que les aliments solides étaient dirigés vers le rumen. Plus récemment, diverses études ont été menées dans le but de déterminer les facteurs responsables de la fermeture œesophagienne. A la suite des travaux de WESTER (I930), Ross (I93I), WATSON et JARRET (I944) et RIECK (I954), il semblait que le rapprochement des lèvres de la gouttière œsophagienne était déterminé par la composition chimique de l'aliment liquide ingéré, en particulier par la présence de certains sels minéraux ou d'albumines. En revanche, d'autres auteurs (WISE et ANDERSON, I939; HEGLAND et al., I957) ont attribué une grande importance au mode de distribution de l'aliment (seau ou tétine). Par ailleurs, Comline et Titchen (I95I) ont montré, chez le Veau décérébré, que la stimulation des récepteurs pharyngiens par la présence de liquides lors de la déglutition entraînait un réflexe de contraction de la gouttière œesophagienne. Les travaux d'Ørskov et Benzie (i969), d'Ørskov, Benzie, et KAy (I970) et de RuckEBUSCH et KAY (I97I) indiquent que chez le jetune adulte entraîné à la prise d'un biberon de lait, la fermeture de la gouttière cesophagienne est devenue un réflexe conditionné indépendant des stimuli chimiques et physiques associés à l'ingestion des liquides.

Lorsque le Veau est maintenu au stade préruminant, il ne reçoit que du lait entier ou des laits de remplacement, lesquels doivent passer directement dans la caillette pour être digérés avec le maximum d'efficacité, selon les processus digestifs du monogastrique. De même, chez le Veau ruminant, il semblerait intéressant d'utiliser le mécanisme de rapprochement des lèvres de la gouttière cesophagienne pour permettre le passage direct dans la caillette des aliments qui, par leur composition en acides aminés et éventuellement leur valeur énergétique, compléteraient utilement les aliments qui sont digérés dans le rumen.

Nos observations ont été menées en vue de préciser la voie suivie par les aliments liquides au niveau de la gouttière œesophagienne chez le Veau préruminant et ruminant.

\section{MATÉRIEL, E'T MÉTHODE}

\section{Principe des mesures}

La voie suivie par les aliments liquides a été déterminée en mesurant la proportion de l'aliment liquide ingéré retrouvée dans le rumen après le repas. Le polyéthylène-glycol 4 ooo a été utilisé comme marqueur. Il a d'abord été introduit dans l'aliment liquide ( 2 à 5 p. Ioo selon l'âge et la quantité offerte) au repas du matin. La concentration en polyéthylène-glycol des échantillons 
de jus de rumen recueillis après le repas $(5$ à 6 prélèvements durant les 6 -7 heures suivant le repas) a été déterminée selon la méthode décrite par Smirh (I959). Les prélèvements ont été effectués par la canule à l'aide d'une seringue munie d'un tube de polyéthylène portant une crépine en son extrémité. La concentration du liquide du rumen en polyéthylène-glycol aussitôt après le repas a été calculée à partir de la régression du logarithme de cette concentration avec le temps (HYDEN, I96I). La quantité d'aliment liquide ingéré a été contrôléc.

La mesure đu volume du rumen a été effectuée 48 heures plus tard en introduisant par la canule 5 à $5^{\circ} \mathrm{g}$ (selon l'âge et le régime) de polyéthylène-glycol 4 ooo aussitôt après le repas du matin au cours duquel une quantité d'aliment identique à celle consommée lors de la mesure précédente était présentée aux animaux. La détermination de la concentration du liquide ruminal en polyéthylène-glycol aussitôt après le repas a été effectuée de la même façon que précédemment. Le volume du liquide du rumen a été calculé à partir de cette mesure (HyDEN, I96I).

La quantité d'aliment liquide présente dans le rumen aussitôt après le repas, a été calculée à partir de la concentration en polyéthylène-glycol du liquide ruminal obtenue lors de la première mesure, et du volume du rumen obtenu lors de la seconde mesure. Les résultats ont été exprimés en proportion de l'aliment ingéré retrouvée dans le rumen.

\section{Animaux}

Dix-huit veaux mâles (I6 Frisons et 2 Pie Rouge) ont été achetés entre les âges de six et quinze jours et élevés en case individuelle. A l'âge de 3 à 4 semaines, ils ont été munis d'une fistule du rumen posée par la voie abdominale après anesthésie générale. Ils ont été utilisés au cours de cinq essais (tabl. I).

\section{TABLEAU I}

\section{Répartition des animaux expérimentaux}

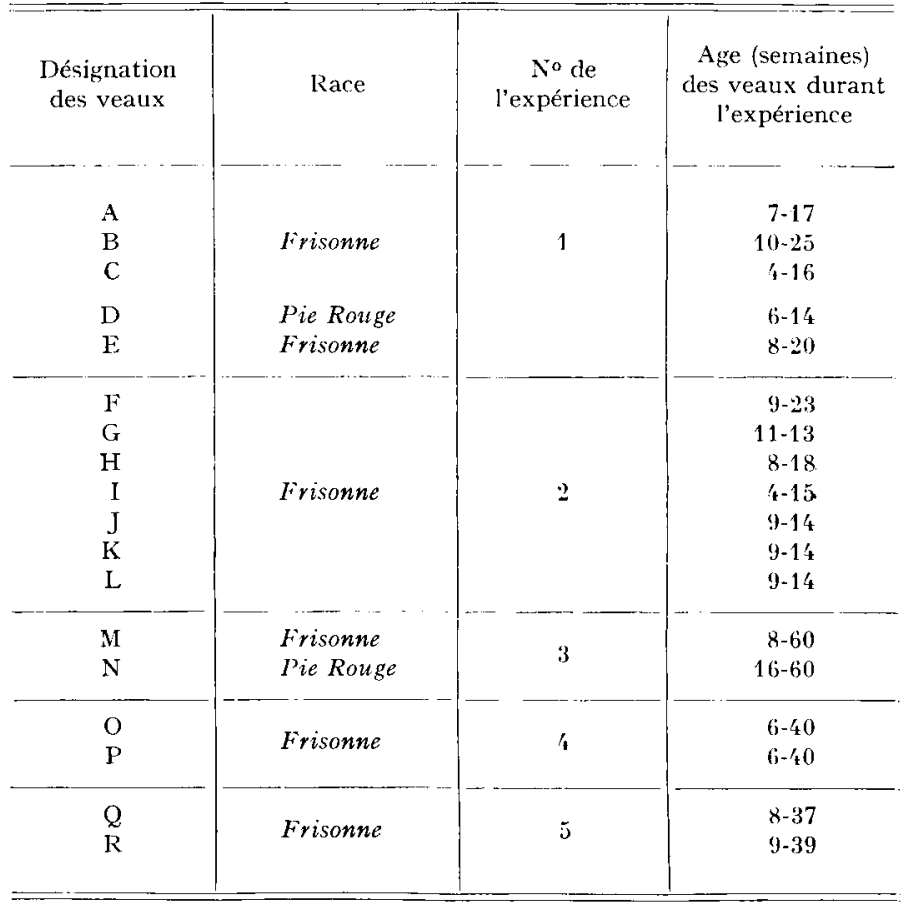




\section{RÉGIMES E'T RÉSULTATS}

\section{Expérience 1}

Cinq veaux (tabl. I) ont été maintenus au stade préruminant. Ils ont reçu 2 fois par jour 4 à $7 \mathrm{~kg}$ selon l'âge, de lait entier, sauf le veau $\mathrm{E}$ qui a reçu un lait de remplacement dont les protéines provenaient exclusivement du lactosérum (aliment " lactoprotéines" décrit par Toullec, Thivend et Mathieu, r971).

Le volume du rumen a augmenté avec l'âge (de I à Io 1 entre 4 et 25 semaines). Moins de ro $\mathrm{p}$. roo du lait ingéré ont généralement été retrouvés dans le rumen des veaux $\mathrm{A}, \mathrm{B}$ et $\mathrm{C}$ recevant le lait de remplacement " lactoprotéines " (fig. I). Entre ces quatre veaux, les différences ne sont pas significatives. En revanche, chez le veau D de race Pie Rouge recevant le lait entier, de fortes proportions de lait ont parfois été retrouvées dans le rumen.

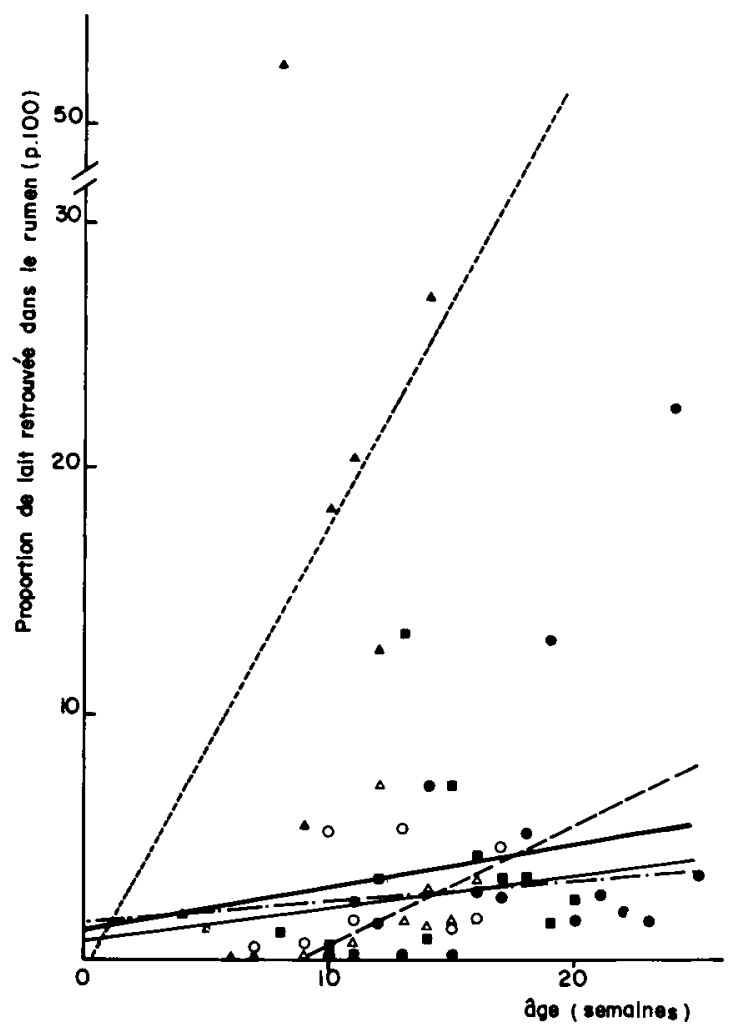

FIG. I. - Proportion de lait retrouvée dans le rumen des veaux préruminants en fonction de l'âge

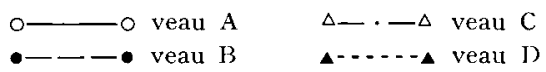

L,e lait entier ingéré au seau passe donc directement dans la caillette, ce qui confirme les résultats obtenus sur le Veau par de nombreux auteurs (ShaL, et Amadon, I928; Wise et Anderson, I939; Hegland et al., I957; Smith, I959 
et Ruckebusch et KAy, I97I) ; il en est de même lorsque la caséine est remplacée en totalité par les protéines du lactosérum. Cependant, l'efficacité de la fermeture de la gouttière œsophagienne n'est pas toujours totale et peut varier avec l'individu (fig. I), comme l'ont observé LAWLOR, Hopkins et KELLY (r97I) chez l'agneau. Chez les veaux Frisons, les pentes des droites de régression entre la proportion $(y)$ de lait retrouvée dans le rumen et l'âge $(x)$ des animaux ne sont pas significativement différentes de o; l'efficacité de la fermeture semble donc indépendante de l'âge, contrairement aux résultats de HEGLAND et al. (I957).

\section{Expérience 2}

Sept veaux (tabl. I) ont été maintenus au stade préruminant. Ils ont reçu chaque jour 2 repas de 4 à $7 \mathrm{~kg}$ de lait (les veaux F, G, H et I ont reçu du lait entier, les veaux $J, K$ et $\mathrm{L}$ un lait de remplacement du commerce riche en poudre de lait écrémé). Par ailleurs, ils ont reçu occasionnellement en substitution au lait, lors du repas du matin, des aliments liquides dont la proportion retrouvée dans le

\section{TABLEAU 2}

Nombre de mesures et proportion (p. Ioo) des divers liquides ingérés dirigés vers le rumen des veaux préruminants

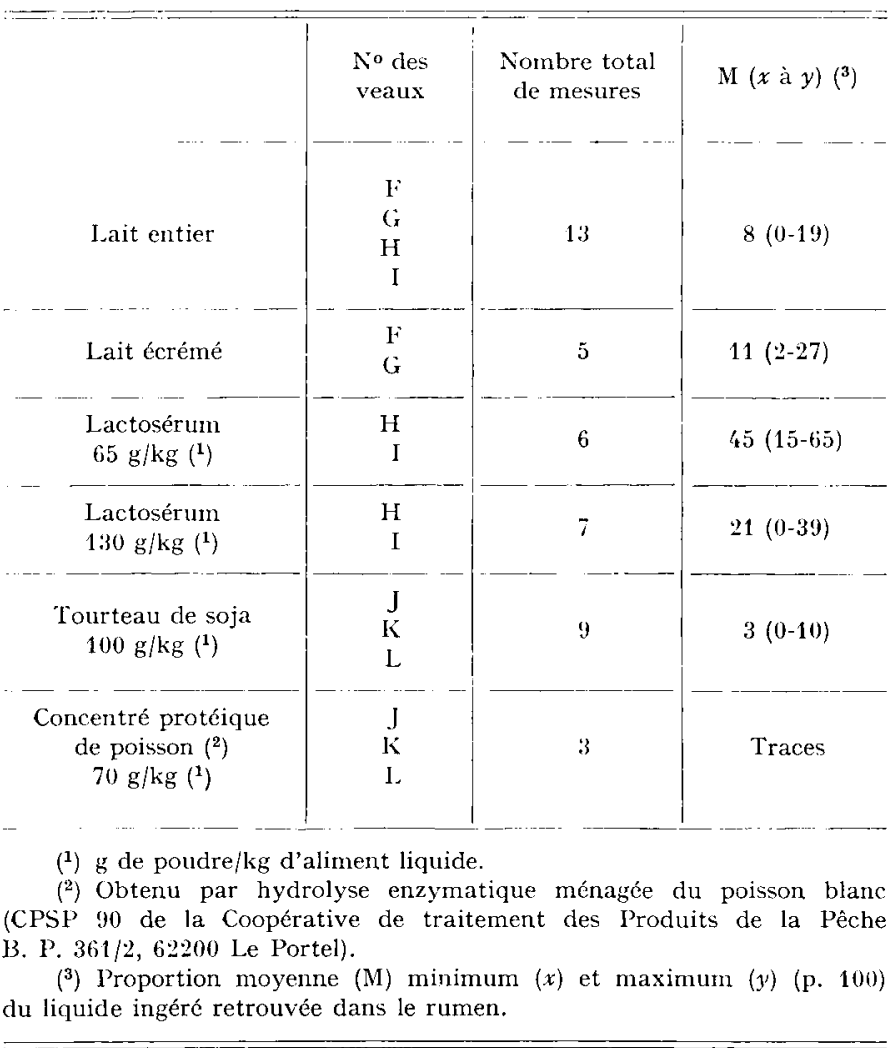


rumen a été mesurée. Les aliments ainsi étudiés ont été le lait écrémé chez les veaux $F$ et $G$, le lactosérum chez les veaux $H$ et $I$, le tourteau de soja, et un concentré protéique de poisson dilués dans l'eau chez les veaux J, K et L (tabl. 2). Le volume du rumen a augmenté avec l'âge (de I à II 1 entre 4 et 23 semaines). La proportion moyenne de lactosérum retrouvée dans le rumen a été relativement importante mais celles de lait écrémé, de suspension de tourteau de soja et de solution de concentré protéique de poisson ont été très faibles (tabl. 2). I,e rapprochement des lèvres de la gouttière cesophagienne semble donc se produire chez le Veau quelle que soit la nature chimique de l'aliment liquide ingéré, comme l'ont observé ØRskov et BENZIE (I969) chez l'Agneau.

\section{Expérience 3}

Deux veaux ont reçu respectivement 5 et $10 \mathrm{~kg}$ de lait par jour, en 2 repas égaux, jusqu'à l'âge de 60 semaines. Ils ont disposé également de foin, d'aliment concentré et d'eau à volonté à partir de l'âge de 6 semaines. Le volume du liquide ruminal a augmenté avec l'âge (de I à 471 entre 8 et 60 semaines). Les proportions

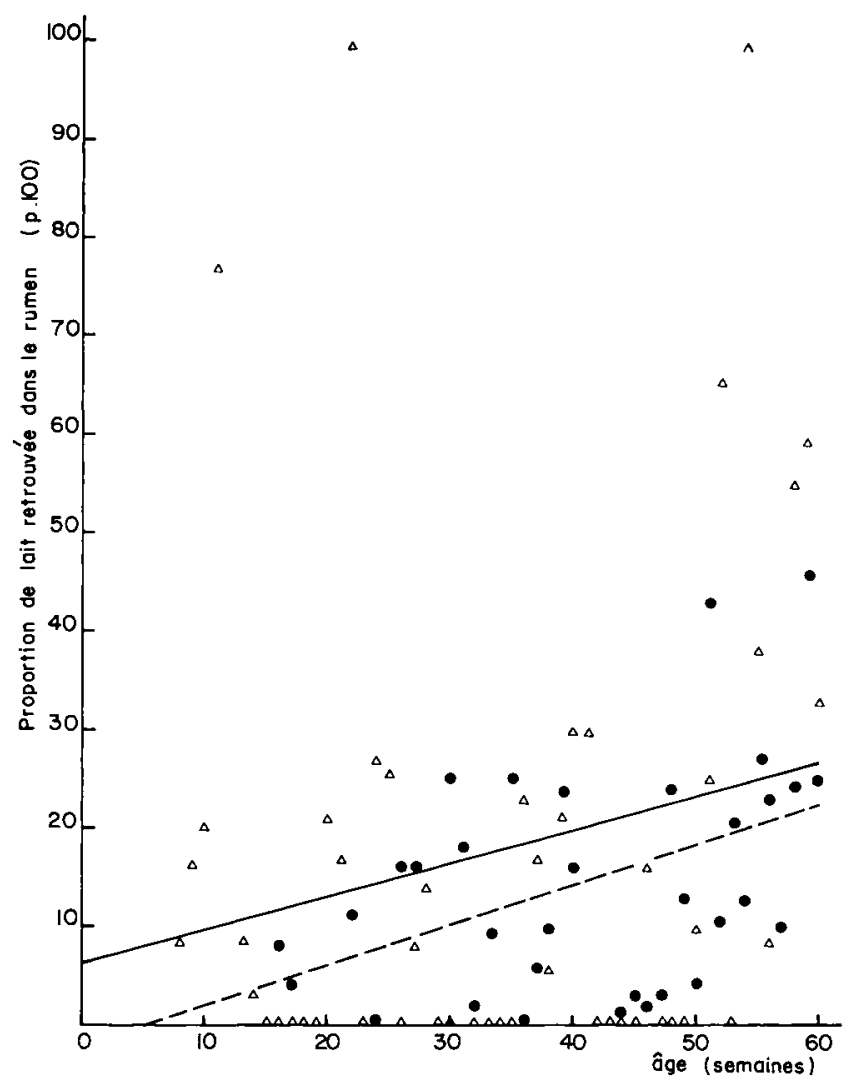

FIG. 2. - Proportion de lait retrouvée

dans le rumen des veaux ruminants non sevrés en fonction de l'áge (p. Ioo)

$\Delta \_\_$veau $M$ (lait $5 \mathrm{~kg} / \mathrm{j}$ )

-_._. veau $\mathrm{N}$ (lait $\mathrm{Io} \mathrm{kg} / \mathrm{j}$ ) 
de lait retrouvées dans le rumen ont été en moyenne de 18 et I4 p. Ioo chez les veaux M et $\mathrm{N}$. L'efficacité de la fermeture de la gouttière œsophagienne a varié d'une mesure à l'autre chez le même individu (fig. 2) ; elle a paru diminuer avec l'âge mais la pente des droites de régression entre la proportion $(y)$ de lait retrouvée dans le rumen et l'âge $(x)$ de l'animal n'a été significative $(\mathrm{P}<0,05)$ que pour le Veau $\mathrm{N}$.

\section{Expérience 4}

Deux veaux ont été sevrés à l'âge de 7 semaines et ont reçu du foin et de l'aliment concentré. Le veau $\mathrm{O}$ disposait d'eau à volonté, le veau $\mathrm{P}$ était privé d'eau pendant la nuit. La proportion d'eau retrouvée dans le rumen a été mesurée entre les âges de 8 et 40 semaines au repas du matin, soit lors du renouvellement de l'eau (veau $\mathrm{O}$ ), soit lors de la présentation de l'eau (veau $\mathrm{P}$ ). Le volume du liquide ruminal a augmenté avec l'âge (de 4 à 291 entre 8 et 39 semaines). L'eau a été retrouvée en proportion plus importante dans le rumen chez le veau qui en disposait à volonté que chez celui pour lequel elle était ôtée la nuit (en moyenne 63 et 29 p. Ioo) (fig. 3).

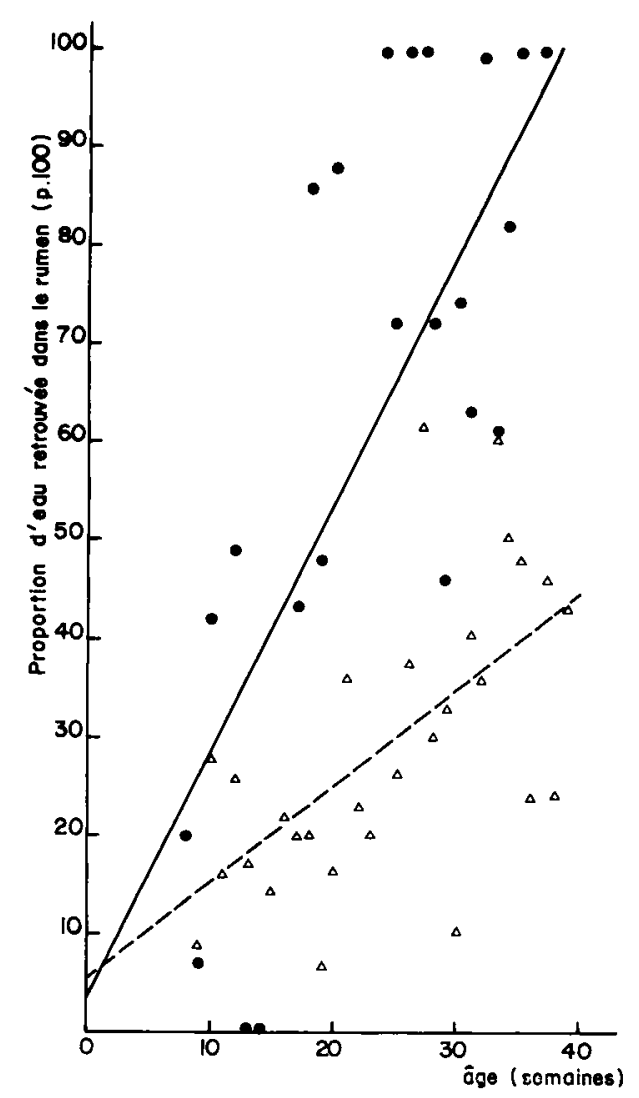

Iiv. 3. - Proportion d'eau retrouvée dans le rumen chez les veaux ruminants sevrés en fonction de l'âge 
Il semblerait donc que la soif ait un effet favorable sur la fermeture de la gouttière œsophagienne. On ne peut cependant exclure l'effet d'une différence liée à l'individu. Par ailleurs, l'efficacité de la gouttière œsophagienne a paru diminuer avec l'âge, mais la pente des droites de régression entre la proportion $(y)$ d'eau retrouvée dans le rumen et l'âge $(x)$ de l'animal n'a été significative $(p<0,05)$ que pour le veau $O$.

\section{Expérience 5}

Deux veaux ont été sevrés à l'âge de 7 semaines et ont reçu du foin et de l'aliment concentré. En outre, ils ont reçu à partir du sevrage, chaque matin, $6 \mathrm{~kg} \mathrm{de}$ buvée exempte d'éléments lactés et composée d'un mélange contenant $32 \mathrm{p}$. Ion de concentré protéique de poisson identique à celui utilisé dans l'expérience 2 , et $64 \mathrm{p}$. Ioo de farine de blé, dilués dans l'eau à $150 \mathrm{~g} / \mathrm{kg}$. Cette buvée a été distribuée jusqu'à l'âge de 40 semaines avec une interruption entre 20 et 30 semaines. Le volume du liquide ruminal a augmenté avec l'âge (de 2 à 271 entre 6 et 40 semaines).

Les proportions de buvée retrouvées dans le rumen lors de la première période de distribution ont été très faibles; elles ont été inférieures à $20 \mathrm{p}$. Ioo dans 96 p. 100 des cas et n'ont jamais dépassé 50 p. Ioo (fig. 4). Cependant, après l'inter-

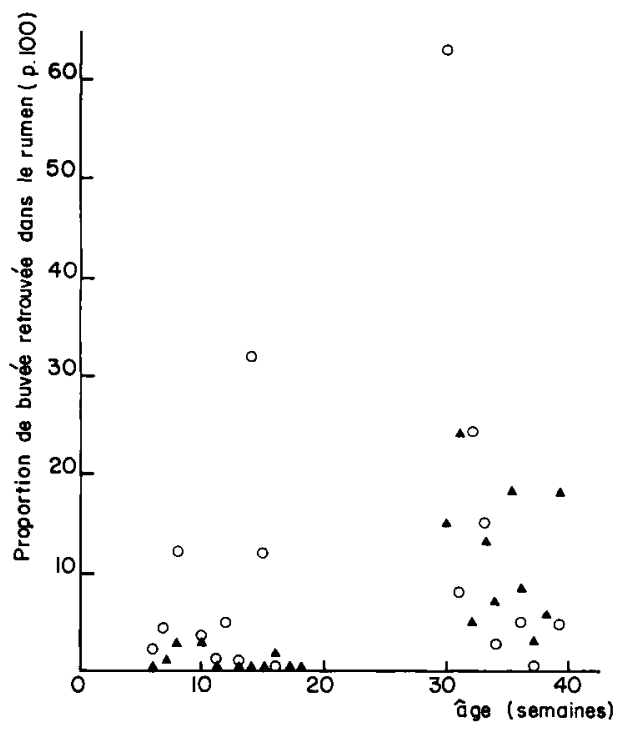

FIG. 4. - Proportion de buvée retrouvée dans le rumen chez les veaux ruminants en fonction de l'âge

o veau $Q$

ruption de la distribution lors de la deuxième période, elles ont été légèrement plus élevées (moins de $20 \mathrm{p}$. Ioo dans 84 p. Ioo des cas). Une buvée exempte d'éléments lactés offerte quotidiennement peut done court-circuiter le rumen chez le Veau ruminant. La fermeture apparaît moins efficace lors de la reprise de la dis- 
tribution après une interruption de ro semaines. Cependant lorsque la buvée est à nouveau offerte quotidiennement, la majeure partie de celle-ci passe directement dans la caillette.

\section{DISCUSSION}

La méthode utilisée ne permet pas de distinguer le liquide introduit dans le rumen lors de la déglutition de celui pouvant provenir d'éventuels reflux à partir de la caillette. Or, Akssenowa (I932), LenketT et Colombus (I935) et Philipson (r939) ont suggéré que le lait ingéré par de jeunes ruminants potvait refluer de la caillette vers le rumen. Cependant WISE et ANDERson (I939) n'ont jamais pu mettre en évidence ce phénomène. De même, MYıREA (I966) a montré que le lait est rarement retrouvé dans le rumen du jeune veau, même lorsque l'animal en ingère de grandes quantités.

Le réflexe de fermeture s'est produit dans presque tous les cas que nous avons étudiés. Cependant l'efficacité du mécanisme a souvent été incomplète et a varié d'un essai à l'autre chez un même individu. Cela pourrait être dû à certaines perturbations subies par les animaux, Comline et TíTCHEN (I95I) et NewhoOK et TITCHen (I974) ayant obtenu un effet dépressif en injectant de l'adrénaline à des veaux. Il est possible également que le mode de distribution utilisé (seau) n'ait pas été le plus favorable, WISE et ANDERSON (I939) et HEGLAND et al. (I957) ayant observé une efficacité meilleure chez le Veau en distribuant le lait à la tétine. Le bol alimentaire plus volumineux lors de l'utilisation du seau pourrait parfois forcer partiellement l'ouverture de la gouttière osophagienne (CoLIN, I87I; HUNGATE, I966) ; cela expliquerait le passage de faibles proportions d'aliment dans le rumen.

Le fait que tous les liquides étudiés, même ceux exempts d'éléments lactés aient pu court-circuiter le rumen, aussi bien chez les veaux préruminants que ruminants, montre que la nature chimique de l'aliment n'a pas à elle seule une action déterminante. Cela semble en contradiction avec les observations de WESTER (I930), Ross (I93I), WATSON (I944) et RIEK (I954) qui indiquaient que la présence de certains éléments chimiques (sels minéraux en particulier) dans les liquides était nécessaire pour déclencher le réflexe de fermeture de la gouttière cesophagienne, mais ces auteurs utilisaient des animaux adultes, chez lesquels le réflexe de fermeture habituellement obtenu avec le lait avait disparu. En outre, ØRSKOV, BENZIE et KAY (I970) et Ruckebusch et KAY (I97I) ont démontré chez l'agneau que la fermeture de la gouttière osophagienne était indépendante de la nature du liquide ingéré puisqu'elle se produisait avant l'ingestion, à la vue du seau ou de la tétine. Il s'agit donc d'un réflexe conditionné. L'hypothèse d'un tel réflexe peut très bien être admise chez le Veau, sans exclure pour autant celle d'un rôle des éléments chimiques qui pourraient être nécessaires à sa mise en place initiale, à la naissance.

L'influence favorable de la soif met en évidence l'importance d'une distribution rationnée des aliments pour qu'ils passent directement dans la caillette. Il semble en outre que le réflexe doive être entretenu par une distribution régulière d'un aliment bien accepté, la fermeture apparaissant plus aléatoire chez certains veaux avec les aliments offerts occasionnellement. L'influence défavorable de l'âge chez les veaux ruminants pourrait être due à une diminution de l'appétit pour l'aliment 
liquide offert en plus du régime de ruminant. Cet effet néfaste n'apparaît pas chez les veaux préruminants qui reçoivent le lait comme seul aliment.

En conclusion, l'ensemble de nos observations montre qu'un aliment liquide bien accepté et ingéré régulièrement par le Veau passe directement dans la caillette grâce au rapprochement des lèvres de la gouttière oesophagienne. Bien que l'efficacité du mécanisme ne paraisse pas toujours totale, en particulier chez le Veau ruminant, elle demeure généralement très élevée au moins jusqu'à l'âge d'un an. Il s'agirait maintenant d'étudier l'intérêt nutritionnel de l'utilisation de ce réflexe chez le Veau ruminant.

Reçu pour publication en aồt 1974 .

\author{
SUMMARY \\ TRANSIT OF LIQUID FOOD THROUGH THE OESOPHAGEAL, GROOVE \\ IN THE PRERUMINANT AND RUMINANT CALF
}

The reflex closure of the oesophageal groove was studied by measuring the proportion of ingested liquid food found in the rumen after the meal. For this purpose, I 8 male calves were fitted with rumen fistulae. Polyethylene glycol 4 ooo was used as a marker; it was introduced directly through the fistula to determine the volume of ruminal liquid or into the food to measure the concentration of polyethylene glycol in the ruminal liquid immediately after the meal. The feeds were offered in an open pail.

I. In five preruminant calves of the Frisian breed, fed with whole milk and maintained at the preruminant stage till the age of 6 months (fig. I), less than Io p. roo of the milk ingested were generally recovered in the rumen. However, in a preruminant calf of the red and white breed, fed under the same conditions, large amounts of milk were sometimes recovered in the rumen.

2. Seven preruminant calves received occasionally liquicl food instead of the milk usually offered (table 2). A very small proportion of the skim-milk, suspension of soybean oil-meal and solution of fish protein concentrate was recovered in the rumen (o to I I p. Ioo) whereas the proportion of whey was higher (20 to $45 \mathrm{p}$. IOO).

3. Two ruminant calves received constantly whole milk till the age of one year (fig. 2). Less than $20 \mathrm{p}$. 100 of the milk were recovered in the rumen in more than $75 \mathrm{p}$. I oo of the trials. The efficiency of the closure of the oesophageal groove seemed to decrease with the age of the animal.

4. In two ruminant calves (fig. 3), the proportion of water recovered in the rumen was much higher in the animal receiving it ad libitum than in that which did not receive any during the night (on an average 63 and $29 \mathrm{p}$. Ioo). The efficiency of the closure of the oesophageal groove seemed to decrease with the age of the animal.

5. Two ruminant calves received, from the age of 7 weeks, a drink without milk as a substitute for the milk replacer (fig. 4). Till the age of 4 months, a small proportion of the drink was recovered in the rumen (less than 20 p. I00 in 96 p. Ioo of the cases). The same phenomenon was observed between the ages of 7 and 8 months, after having interrupted for 2 months the administration of the drink.

Thus, in the calf, a very large proportion of the liquid food voluntarily ingested from the pail reaches directly the abomasum whatever their chemical nature may be. However, the proportion recovered in the rumen seems to increase with the age of the ruminant calf and in particular after the age of one year.

\title{
RÉFÉRENCES BIBLIOGRAPHIQUES
}

Akssenowa M. J. cité par Wise G. H., Anderson G. W., I939. Factors affecting the passage of liquids into the rumen of dairy calf. I. Method of administering liquids: drinking from open pail versus sucking through rubber nipple. J. Dairy Sci., 22, 697-705.

Colın G., I871. Traité de physiologie comparée des animaux. Baillière et Fils, Paris, 638 p. 
Comline R. S., Titchen D. A., I95I. Reflex contraction of the oesophageal groove in young ruminants. J. Physiol., 115, 2 I0-226.

Faber J., cité par Hungate R. E., I966. The rumen and its microbes. Academic Press, New York, I6I $\mathrm{p}$.

Flourens P., 1844 . Mémoires d'anatomie et de physiologie comparées. Baillière et Fils, Paris, 36 p.

Hegland R. B., Lambert M. R., Jacobson N. L., Payne L. C., r957. Effect of dietary and managemental factors on reflex closure of the osophageal groove in dairy calf. J. Dairy Sci., 20, 1ro7III3.

Hungate R. E., I966. The rumen and its microbes. Academic Press, New York, I6I p.

Hyden S., I96r. Determination amount of fluid in the reticulo-rumen of the sheep and its rate of passage to the omasum. Kun. Lant. Ann., 27, 5 I-79.

Lawlor M. J., Hopkins S. P., Kealy J. K., I97I. The functioning of the oesophageal groove reflex and comparison of the performance of lambs fed individually and in groups. Brit. J. Nutr., 26, 439-448.

Mylrea J. P., I966. Digestion in young calves fed whole milk ad libitum and its relationship to calf scours. Res. Vet. Sci., 7, 407-4I6.

Newноок J. C., Tiтchen D. A., I974. Effects of vagotomy, atropine, hexamethonium and adrenaline on the destination in the stomach of liquids sucked by milk-fed lambs and calves. J. Physiol., 237, $243^{-258 .}$

Orskov E. R., BenziE D., I969. Studies on the osophageal groove reflex in sheep and on the potential use of the groove to prevent the fermentation of food in the rumen. Brit. J. Nutr., 24, $785-794$.

Orskov E. R., BenziE $\quad$ D., Kay R. N. B., I97o. The effect of feeding procedure on closure of the cesophageal groove in young sheep. Brit. $J$. Nutr., 24, 785-795.

Phillipson A. T., I939. The movements of the pouches of the stomach of sheep. Quart. J. Exp. Physiot., 29, 395-4I 5 .

RiEK R. F., I954. The influence of sodium salts on the closure of the œsophageal groove in calves. A ust. Vet. J., 30, 29-37.

Ross I. C., I93I. The passage of fluids through the ruminant stomach. A ust. Vet. J., 7, I22-I34.

Ross I. C., r936. The passage of fluids through the ruminant stomach. III. The effects of volume of fluid and the site of stimulation on the reflex closure of the oesophageal groove. Aust. Vet. $J ., 12,4^{-8}$.

Ruckebusch Y., Kay R. N. B., ig7r. Sur le réflexe de la fermeture de la gouttière oesophagienne. Ann. Biol. anim. Bioch. Biophys., 11, 28I-282.

Schalk A. F., Amadon R. S., 1928. Physiology of the ruminant stomach (bovine). Bull. N. Dak. Agric. Exp. Stn., $\mathrm{n}^{0} 2 \mathrm{I} 6$.

Smith R. H., I959. The development and function of the rumen in milk fed calves. J. Agr. Sci., $52,72-78$

Toullec R., Thivend P., Mathieu C.-M., I97I. Utilisation des protéines du lactosérum par le Veau préruminant à l'engrais. Ann. Zootech., 21, 319-33I.

Watson R. H., 1944. Studies on deglutition in sheep. I. Observations on the course taken by liquids through the stomach on the sheep at various ages from birth to maturity. Bull. Commonw. Scient. Ind. Res. Org., 180, 7-94.

WATSON R. H., JARRET I. G., r944. Observations on the influence of copper salts on the course taken by liquids into the stomach of sheep. Bull. Commonw. Scient. Ind. Res. Org., 180, 95-126.

Wester J., I930. The rumination reflex in the ox. Vet. J., 86, 40I-4ro.

Wise H., Anderson G. W., r939. Factors affecting the passage of liquids into the rumen of the dairy calf. I. Method of administering liquids : drinking from open pail versus sucking through a rubber nipple. J. Dairy Sci., 22, 697-705. 